\title{
Corporate Governance And Directors' Remuneration In Selected ASEAN Countries
}

Dr. Mohammad Talha, King Fahd University of Petroleum \& Minerals, Saudi Arabia Abdullah Sallehhuddin, Multimedia University, Malaysia Md Shukor Masuod, Multimedia University, Malaysia

\begin{abstract}
This paper briefly discusses the corporate governance and directors' remuneration as being practiced by five different ASEAN countries i.e. Singapore, Malaysia, Indonesia, Philippines, and Thailand. Governance is about how an entity is being directed and controlled, while corporate governance is about a system, procedure or mechanism of balancing between directing and controlling business entities' internal matters and the demand of their external shareholders and stakeholders. The paper summarizes the development of corporate governance and directors' remuneration in these countries. An attempt has also been made to highlight issues regarding the need of disclosure of individual director's remuneration, the need of shareholders' approval on directors' remuneration, the need of shareholders' approval on stock based incentive plan, approval of directors' remuneration by a committee at board level, the separation of role of the Chairmen of Board of Directors and Chief Executive Officers, and the recommended maximum length of period offered to directors. It later focuses on the progress made by these countries in further uplifting their corporate governance practices. The paper also examines some arising pertinent and puts forth some recommendations on how the future direction of the development of corporate governance in ASEAN countries with respect to directors' remuneration shall take shape.
\end{abstract}

Keywords: Corporate Governance, Director's Remuneration, CEO, BOD.

\section{INTRODUCTION}

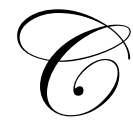

orporate governance is one of the contemporary and controversial areas in business environment. It used to be considered as an exclusive discussion among accounting practitioners and audit communities, however, currently it is becoming more important across knowledge disciplines as well as in real business world. Corporate governance has received a great deal of public attention due to its evident importance for the economic and financial health of corporations and society in general. The cases like Enron, WorldCom, Adelphia, Parmalat and other high profile scandals, which happened during the last decade, have also attracted the attention of various groups of people towards the importance of corporate governance. In ASEAN countries especially, corporate governance received more attention after the financial crisis of 1997, which badly hit several countries like Thailand, Indonesia, Philippine, and Malaysia. Accepting that some of the factors that aggravated the situation were external in nature, the authorities have taken great initiatives to improve the internal situation particularly corporate governance in local economic sectors. Greater emphasis was laid on transforming the local financial institutions, equity market and corporate board leadership to make them more resilient, transparent, ethical and credible entities.

In general, corporate governance can be defined as the rules and incentives by which the management of a company is directed and controlled to maximize the profitability and long-term value of the firm for shareholders while taking into account the interests of other legitimate stakeholders (Stone, Hurley and Khemani, 1998). The 
principal players in corporate governance are the shareholders, management and the board of the directors. Other stakeholders include employees, suppliers, customers, banks and other lenders, regulators, the environmentalists and the community at large. Some of the corporate governance issues, which have taken a center stage and are becoming popular research topics among the scholars, lie in of the rights and treatment of shareholders especially the minority shareholders, the responsibility of board members, financial disclosure and transparency, the role of independent and non independent directors, the impact of corporate governance on a firm's performance, and the disclosure of directors' remuneration.

Directors' remuneration is the payment made for services or employment of directors on the board the company or corporation. This includes the basic salary and other monetary or non-monetary benefits that an executive receives during his or her tenure. Generally boards of directors' are categorized into two different categories, that is, executive and non-executive directors. Executive directors are regarded as non-independent directors since they are assigned specific operating roles within the entities such as finance, administration and operation. Non-executive directors meanwhile are regarded as independent directors since they are not directly involved operating function. Instead they are given tasks to monitor the executive directors such as chairing remuneration committee, audit committee and nomination committee within the board's purview. Directors' remuneration should be embraced in the corporate governance process. The way in which it is handled can have a damaging impact on a company's reputation, and on the overall morale of the company employees. The level and make-up of remuneration should be sufficient to attract and retain the directors needed to run the company successfully.

Company management has brought about significant changes in directors' remuneration because of the convergence of a number of factors that necessitated re-examination of the structure and make-up of remuneration. The convergence factors are continuing trend towards greater transparency, accountability and linkage between pay and performance, changes in the accounting and tax treatment of stock based compensation, and increasing accountability of the board of directors for corporate governance and sustainable value creation.

There are many types of directors' remuneration or benefit plans, which are designed to help compensate executives and encourage them to remain with the company for long. One of them is nonqualified deferred compensation plan. A nonqualified deferred compensation plan lets company to set aside funds to benefit a selected group of highly compensated executives. It allows the company to design a deferred compensation plan for executive pretax salary deferral, employer contribution or both. Executive bonus plan is also one of them. An executive bonus plan is a way to compensate selected directors, regardless of their income and position, by paying a cash bonus or by directly purchasing an investment on directors' behalf. The bonus is a tax-deductible expense to the company and taxable compensation for the directors. Besides, directors may be offered executive life insurance, which is to protect their families in the event of premature death.

Some performance incentives come from ownership of the company's shares, while the relationship between share ownership and firm's performance was dependent on the level of ownership. For example, increase in ownership above 20 percent causes management to become more entrenched, and less interested in the welfare of their shareholders. Firm performance is positively associated with share option plans. These plans direct executives' energies and extend their decision horizon toward the long-term, rather than the short-term, performance of the company. However, the point of view came under substantial criticism in the wake of various security scandals including mutual fund and option grants.

\section{LINK BETWEEN CORPORATE GOVERNANCE AND DIRECTORS' REMUNERATION}

The link between corporate governance and directors' remuneration can first be explained by the agency theory. Agency theory refers to the relationship between management and shareholders, in which management acts as agent for shareholders' best interest. The management (agent) is required to operate the business mainly for the best interest of shareholders (principal). According to Fama and Jensen (1983) agency theory, although individual members of the business team act in their own self-interest, the well being of each individual depends on the wellbeing of the other team members and on the performance of the team in competing with other teams. 
The agency relationship arising from the separation of ownership from management is sometimes characterized as agency problem. Conflict of interest may arise. One of the reasons is executives receive their salaries, bonuses and stock option in a different form from shareholders who receive dividends and capital gains. Therefore, the management tends to use their authority to pay themselves excessive salaries and benefits. They will decide to retain profits rather than paying out as dividends in order to reduce the financial risk. Besides, management and shareholders have different attitude for risk avoidance as the results of the operation may influence their pay, for example around diversification activities.

The management will only do their best to improve the financial performance of their company when the pay is often related to the size or profitability of the company. As a consequence, shareholders tend to exercise control and influence the behaviors of the executives by designing incentive schemes for directors with an attempt to align the interests of shareholders and directors. First, directors will be rewarded financially for maximizing shareholders interest. Conversely, when there is no value created for shareholder there will be no reward for them, except the basic salary and benefits. Such schemes may include plans whereby senior executives obtain shares, perhaps at a reduced price, thus aligning financial interest of directors with those of shareholders. Other similar schemes tie levels of bonuses and compensation of the executives to shareholders returns. Part of directors' compensation is deferred to the future to reward long-run value maximization of the company and deter short-run executive action, which harms corporate value.

The remuneration committee is established at board level for recommending to the board a remuneration framework for executives. They are having the objective to provide the remuneration packages, which are able to attract, retain and motivate directors to manage the business in the interest of shareholders and to align the interest of both the parties. Statutory requirements in some countries require all the listed companies to publish a director's remuneration report with their annual financial statement. Public listed company has to comply with the rules, regulations and best practices. The company is required to list down long-term incentives as well as wages received by directors individually. This will enhance transparency. Stock exchange regulations also require listed companies to have full remuneration disclosures and policies for executives. This will decrease the risk of excessive remuneration. The aim is to protect the shareholders and potential investors. Trust and fairness are important elements that must exist in the issue of directors' remuneration. The procedures and systems in the company require showing that trust exists between shareholders and executives and a company is running with a reasonable standard of fairness.

\section{DISCLOSURE OF INDIVIDUAL DIRECTORS' REMUNERATION}

According to Malaysian Code of Corporate Governance, the annual report shall disclose the remuneration of each director. The disclosure requirement recognizes and promotes important principles of fairness and accountability. The principle also implies that the report should be in the name of the board, rather than of the remuneration committee. According to Listing Requirement of Bursa Malaysia (previously known as Kuala Lumpur Stock Exchange), App. 9C (12), annual report of the companies are required to have a statement of how the companies have applied the principles set out in Part 1 of the Malaysian Code of Corporate Governance (MCCG) to their particular circumstances. They are required to have disclosure on director's remuneration, which includes the level and make-up of remuneration and the procedure. Besides, companies are required to disclose aggregated figure of remuneration of executives with categorization, including executives' fees, salaries, bonuses, commissions, compensation for loss of office, benefits in kind based on an estimated money value distinguishing between independent and non independent directors, and the number of directors whose remuneration falls in each successive band of RM 50, 000. However, disclosure of directors' remuneration is not mandatory.

Stated in Singapore Code of Corporate Governance, each company is to clearly disclose its remuneration framework, policy, level and mix of remuneration in the company's annual report. It enables shareholders or investors to understand the link between remuneration paid to executives, and company's performance. Each directors name and amount of payment is disclosed in bands of $\mathrm{S} \$ 250,000$ plus a breakdown (in percentage terms) of each director's remuneration earned through basic/fixed salary, variable or performance-related income/bonuses, benefits in kind, and stock options granted and other long-term incentives. These requirements are further extended to the company's top five executives. Further, the remuneration of employees who are immediate family members 
of directors or Chief Executive Officers, and whose remuneration exceeds $\$ \$ 150,000$ during the year shall also be reported. The code also requires the disclosure of comprehensive employees share schemes. "According to Thailand's The Principles of Good Corporate Governance for Listed Companies 2006' issued by The Stock Exchange of Thailand the company shall disclose fully in the company's annual report the reward paid to directors. Besides the company shall also disclose the directors' and top executive's remuneration policies that relate to the contributions and responsibilities of each person. The disclosure includes the form and the amount of payment. Meanwhile, if the director of the company also sits as director in subsidiary companies, the amount representing the director's fee paid by those subsidiaries shall also be reported.

Even though, the Indonesian Accounting Standards Board (DASK) is not developing the accounting standard to regulate the disclosure of executive remuneration in companies' financial statement, the Indonesian Code of Corporate Governance urges them to do so. It is in fact, in line with the Ministry of Government Enterprise instruction to all government enterprises to implement good corporate governance practices. The Jakarta Stock Exchange has also obliged public listed companies to implement the same good governance practices. The Indonesian corporate governance framework ensures that timely and accurate disclosure is made on all material matters regarding the corporation, including financial situation, performance, ownership, and governance of the company. Disclosure should include, but not be limited to material information on (1) the financial and operating results of the company, (2) company objectives, (3) major share ownership and voting rights, (4) members of the board and key executive management and their remuneration, (5) material foreseeable risk factors, (6) material issues regarding employees and other stakeholders and (7) governance structure and policies. The disclosure of directors' remuneration is one of the disclosures of material information in the corporate governance framework in Indonesia. The reason is, as key executives in the corporation, their decisions affect the financial status and the shareholders wealth. In addition, the shareholders know the actual amount of money spent on the executives, and allow them to evaluate whether their performance is worth that much amount of remuneration. Besides, the code encourages the disclosure of each executive's remuneration.

The Philippine Securities and Exchange Commission (SEC) is a principal player in imposing good corporate governance practices in the country. It has issued the Memorandum Circular 2, Series of 2002 also known as the Code of Corporate Governance under resolution No. 135 dated April 4, 2002 (Baltazar, 2002). The code now is effective and must be followed under pain of penalty. The Philippine code requires the disclosure of more transparent internal workings of the company and cash flows. Therefore, the disclosure of individual director including stock option is required and becoming vital and dominant theme in the code. In addition, the code perceives that this information is material and will influence the cash flows of company. The transparent internal works and cash flow including the directors' remuneration can avoid the misappropriation and mismanagement of the company's assets. Besides, the Philippine's companies shall promulgate and adopt the corporate governance rules and principles stated in the code. Any company, which fails to adopt a manual of governance in the code shall be penalized P100, 000 after due notice and hearing.

\section{IS SHAREHOLDERS' APPROVAL REQUIRED FOR DIRECTORS’ REMUNERATION?}

In Malaysia, Under Table A: Articles of Association in Schedule Four of the Companies Act, directors' remuneration is subject to shareholders' approval; however no definition is provided by the Act as to what constitute remuneration. Companies are free to adopt the Table A as their company articles or make amendments to it before adoption. In practice however, most companies only table directors' fees at the shareholders' annual general meeting for their approval as required by Bursa Malaysia Listing requirement Under Para 7.26. The practice is also similar in Singapore.

According to Corporate Governance Center of the Stock Exchange of Thailand, remuneration committee is responsible for setting the transparent criteria and the form of payment to directors and top executives and presenting the recommendation to the board. Whilst the board approves top executives' remuneration, the shareholders vote to approve that of directors. The board of directors shall not approve its own remuneration. The level and composition of remuneration should be appropriate and high enough to keep qualified directors but they should not be overpaid. 
In Indonesia, the national corporate governance code, which was issued on April 2001 by National Committee on Corporate Governance (NCCG), states that the rights of shareholders shall be protected and they shall exercise their rights by relying on the appropriate procedures that have been adopted by the companies concerned and these procedures shall be required under applicable regulations having the force of law. One of the responsibilities of shareholders with respect to the above question is the appointment of the members of the Dewan Komisaris (board of commissioners) and the Direksi (board of managing directors) of the company and their remuneration. At the general meeting, shareholders have the right to appoint the members of those boards and determine the board members' remuneration. In short, the code states that the shareholders are entitled to vote for the directors' remuneration in Indonesia.

The Philippine code states the six rights of shareholders which include the voting right, pre-emptive right, power of inspection, right to information, right to dividends and appraisal right. Thus, right number six of shareholders in the code states that the shareholders are entitled to vote for the remuneration of the directors. The code also allows the shareholders to vote for additional benefits, compensation and deduction of appraisal to directors.

\section{IS SHAREHOLDERS’ APPROVAL REQUIRED FOR STOCK-BASED INCENTIVE PLANS?}

The code of Malaysia is silent on the above issue. Normal practice is that the remuneration committee recommends such incentives for executive directors and top executives before being approved by the board. However, given ownership concentration in Malaysia and elsewhere in Asia, shareholders' basic rights will not sufficiently address minority shareholders' protection concerns and their fair treatment. Investor's confidence in the fact that the capital they provide will be protected from misuse or misappropriation by controlling shareholders, managers and directors is an important factor in capital markets. Malaysia has a number of provisions designed to curb abusive behavior by interested, related or connected parties, which range from provisions requiring shareholder approval upon disclosure to absolute prohibitions in some cases. In recent years, many Singapore companies have adopted employee share option schemes (ESOS) as a means of compensating executives, directors and employees (Mak and Ching, 2000). However, most companies only issue options to senior executives and directors, although there have been several recent instances of the adoption of broad-based ESOS that include stock options for lower level employees also. Stock options can be an effective tool for aligning the interest of managers or employees and shareholders and provide a stronger link between pay and performance, and therefore perform an important corporate governance function. However, providing proper incentives through options requires a well - designed ESOS.

Preventing abuse in the use of options requires transparency in the determination of option to rules in the Singapore Exchange (SGC) Listing Requirements (Practice Note No. 9h) and the Companies Act 1990. The Act, Section 201, requires the number and class of shares for which options are issued, date of expiration of the options, and basis upon which the options may be exercised to be disclosed in the directors' report. The maximum expiration term of options is 10 years. The SGX rules relate to matters such as exercise price, expiration terms, vesting periods, total size of the scheme, number of options issued to particular individuals, participation in ESOS, and administration of the ESOS. In general, options are to be issued at the market price. However, options may be issued at a discount of up to 20 percent provided they have a minimum vesting period of 2 years and are approved by shareholders. Controlling shareholders and their associates who are directors or employees may participate in the ESOS provided independent shareholders' for each person approve them. Award of option to controlling shareholders, awards to employees receiving in aggregate 5 percent or more of the option, and aggregate number of options to be made available for grant have to be approved by independent shareholders.

In Thailand, the code recognizes the rights of shareholders to participate in material corporate actions by requiring that shareholders meeting approve such actions in advance. These actions include increase or decrease of capital, transactions resulting in transfer of material assets or business of the company to another party and extraordinary transaction. Moreover, it requires those transactions to be approved by the shareholders by super majority resolution. Furthermore, Stock Exchange Commission regulations on ESOS, share offering at below market price, and delisting of securities provided shareholders with 5 percent or 10 percent veto rights. 
In Indonesia, despite its limited scope in application, the new law on stock-based incentive for executives and employees of listed companies is a major step towards the establishment of a more comprehensive regulatory system for employee stock option schemes. The government systematically provides for the first time detailed requirements for granting shares to employees, disclosure standards, pricing mechanisms and other fundamental procedures for the implementation of stock option and stock-based incentive schemes for listed companies. The existing code of corporate governance however addresses the need of shareholders' approval to reward stock-based incentives and bonus payment to directors. In Philippine, the code provided appraisal right to shareholders, which allows them to exercise it in case any amendment to the articles of company has the effect of changing or restricting the rights of any shareholders or class of shares, or of authorizing preferences in any respect superior to those outstanding shares of any class, or of extending or shortening the term of corporate existence.

\section{MUST A REMUNERATION COMMITTEE RECOMMEND DIRECTORS' REMUNERATION PROPOSALS?}

It is not necessary for remuneration committee, which normally comprises independent directors, to approve executive director's remuneration proposals. It depends on the balance between the proposed reward and actual performance of the executive directors. Therefore, the committees must ensure that the remuneration requested must reflect executive directors' contribution to the company and also make a decision by ensuring that any termination payments are fair to the individual and the company. In Malaysia, the function of remuneration committee is to recommend to the board the remuneration of the executive directors in all its forms, drawing advice from outside as necessary. Executive directors should not take part in deciding their own remuneration. In the directors' report, the membership of the remuneration committee should appear. The remuneration committee also is encouraged to consist of wholly or mainly non-executive directors. The board as a whole is also responsible to determine the remuneration package of non-executive directors, including the Chairman of BOD. As a conclusion, the individuals concerned shall abstain from discussing their own reward.

In Singapore, the remuneration of directors and top executives is designed and recommended by the remuneration committee, which comprises independent directors. The Code of Corporate Governance 2005 requires a formal and transparent procedure for developing policy on director's remuneration and for fixing the reward package of individual directors. If necessary, the remuneration committee shall also seek for expert advice inside or outside the company on reward of all directors. In Thailand, the Stock Exchange of Thailand (SET) establishes the Code of Best Practice for Directors of Listed Companies as guidelines for all board members in corporate governance. Based on the code, the company should have a written and transparent policy concerning the remuneration of directors and top management. The code states that the committee recommends the rewards of executive directors to the board, before being approved by shareholders during a general meeting. The remuneration of directors, who are appointed to specific committees or are assigned any additional duties, shall reflect the responsibilities assigned by the board.

In Indonesia the remuneration committee is responsible for preparing and providing recommendation in respect of the assessment of remuneration system, the granting of options, such as stock option, pension rights and redundancy and other compensation schemes for both Dewan Komisaris and Direksi members. For Philippine, one of the remuneration committee's duty is to review and recommend remuneration of the directors and top corporate officers with an intention to achieve corporate goals or objectives. In addition, the committee evaluates the performance of the directors and executives in light of those corporate goals or objectives and set the remuneration level for them.

\section{SEPARATION OF ROLES BETWEEN THE CHAIRMAN OF BOARD OF DIRECTORS (BOD) AND CHIEF EXECUTIVE OFFICER (CEO)}

The Chairman of board of directors often plays a key role in corporate governance. He has to protect the shareholders' welfare and wealth; it is his responsibility to endorse the organization's strategy, develop directional policy, appoint, supervise and remunerate senior executives and to ensure accountability of the organization to its owners (shareholders) and authorities. CEO is the highest-ranking corporate officer, administrator, who is in charge of total management of a corporation. It is highly recommended that the Chairman of BOD and CEO's role is separate and not held by the same individual in order to avoid conflict of interest and to promote good governance. 
Malaysian Code on Corporate Governance clearly explains the separation of role the Chairman of BOD and CEO. It aims to avoid individual from unfettered powers of decision. A director who is beholden to the CEO will have difficulty in acting independently, at least in assessing management of a company. Where the roles are combined, there should be a strong independent element on the board. There shall be a public explanation about the decision to combine both roles.

As stated in Singapore Code of Corporate Governance 2005, we know that there is clear division of roles and responsibilities at the top of the company which is the working of the Board and the executive accountability of the company's business. This existing clear roles division will ensure a balance of power and authority, such that no one individual represents a considerable concentration of power. Therefore, the Chairman and CEO should in principle be separate person. It helps to enhance accountability and allows greater capacity to the board for independent decision-making. The delegation of roles between the Chairman and CEO is clearly established, set out in writing and agreed by the Board. If there is any close relationship between the Chairman and CEO, it shall be disclosed too. In the unlikely event, the Chairman of BOD and CEO is the same person; the code recommends the appointment of an independent non-executive director to be the head independent director.

From the guideline of Code of Best Practice for Directors of Listed Companies of Thailand, there is need to have separation of duties of the Chairman of BOD and CEO. The Chairman shall be an independent director and shall not be the same person as the CEO or managing director. In Indonesia, the code encourages such separation of role. However, in closely held companies, it is a general culture, that the CEO is also the Chairman of BOD. Specifically, one person often shares the Chairman and CEO titles while another person takes the presidency or may become Chief Operating Officer (COO). In Philippine, the code also recommends that the roles of the Chairman of BOD and CEO be separated to ensure an appropriate balance of power, increased accountability and greater capacity of the board for independent decision making. Furthermore, they are to ensure that their organizational and procedural controls are adequate and effective to ensure reliability and integrity of financial and operation information, effectiveness and efficiency of operations, safeguarding of assets and compliance with laws, rules, regulations and contracts.

\section{RECOMMENDED MAXIMUM LENGTH OF CONTRACTS FOR DIRECTORS AND TOP EXECUTIVE}

Generally, recommended maximum length of directors' contracts differs among countries and companies. It depends on the role of directors', the nations employment regulation and also the performance of the particular director especially for extension of contracts. Current best practice on the length of contract period offered to CEO in Malaysia is three years and indeed this is already the norm in many Malaysian businesses. When the contract reaches the third year then the company may renew the contract of the CEO depending on his or her actual performance. Meanwhile, board members are required to submit themselves for re-election at regular intervals or at least every three years. It is the board's responsibility to appoint new board members and the shareholders' responsibility is to re-elect them. Such re-election at regular intervals not only promotes effective boards but afford shareholders the opportunity to review the board members' performance and, in turn, where necessary, replace them. The length of contract period of CEO or top executive in Singapore is normally two years. The code however encourages that there should be a fixed appointment for all executive directors and the period should not be extremely long or with too much removal clauses. Besides that, all board members shall be eligible for re-election. A description of the process for the selection and appointment of new members to the board should be disclosed. They shall include disclosure on the search and nomination process.

In Thailand, in normal circumstances, the length of contract period of CEO is 12 months. Boards of director's members are required to submit themselves for re-election at regular intervals or at least every one-year. In Indonesia, the employment law indicates maximum 12 months' period of working permit for expatriate inclusive of foreign CEO. As the corporate governance code of the county is silent on the issue, general practice is also 12 months. In fact, the Central Bank of Indonesia indicates the same period for head honcho of commercial banks there. For Philippine, the initial contract offered to top executives is 18 months and could be extended to 5 years based on performance. 


\section{CONCLUSION}

The preceding analysis shows several initiatives taken by selected ASEAN countries' authorities to enhance the corporate governance policies and practices surrounding directors' remuneration issue. The governance initiatives taken are mainly based on the agency theory concept to further minimize potential agency problem between the agent (executives) and the principal (shareholders). The summary of above findings is tabulated in Table 1 at the end of this article.

Table 1: Summary of Corporate Governance and Executive Remuneration in Selected ASEAN Countries

\begin{tabular}{|l|c|c|c|c|c|}
\hline $\begin{array}{l}\text { Corporate Governance } \\
\text { Policies and Practices }\end{array}$ & Malaysia & Singapore & Thailand & Indonesia & Philippine \\
\hline $\begin{array}{l}\text { Individual director } \\
\text { remuneration disclosure }\end{array}$ & Yes & Yes & Yes & Yes & Yes \\
\hline $\begin{array}{l}\text { Shareholders approval } \\
\text { on directors } \\
\text { remuneration }\end{array}$ & Yes & Yes & Yes & Yes \\
\hline $\begin{array}{l}\text { Shareholders approval } \\
\text { on stock-based incentive } \\
\text { plans }\end{array}$ & $\begin{array}{l}\text { Assumed not necessary (it } \\
\text { is not discussed within the } \\
\text { scope of provisions } \\
\text { requiring shareholders } \\
\text { approval) }\end{array}$ & $\begin{array}{l}\text { Yes, and approved } \\
\text { by independent } \\
\text { Shareholders. }\end{array}$ & Yes & Yes & Yes \\
\hline $\begin{array}{l}\text { Remuneration } \\
\text { committee recommends } \\
\text { on directors } \\
\text { remuneration }\end{array}$ & Yes & Yes & Yes & Yes & Yes \\
\hline $\begin{array}{l}\text { Separation roles of the } \\
\text { Chairman of BOD and } \\
\text { CEO }\end{array}$ & Yes & Yes & Yes & Yes & Yes \\
\hline $\begin{array}{l}\text { Recommended } \\
\text { maximum length of } \\
\text { contract }\end{array}$ & 3 years & 2 years & $\begin{array}{l}1 \text { years/12 } \\
\text { months }\end{array}$ & $\begin{array}{l}1 \text { years/12 } \\
\text { months }\end{array}$ & $\begin{array}{l}18 \text { months with } \\
\text { possible } \\
\text { extension to 5 } \\
\text { years }\end{array}$ \\
\hline
\end{tabular}

As a way forward, good corporate governance practices continue to progress among ASEAN countries. The stiff competition to attract foreign investors and the rise of India and China as new world economic super powers continues to pressure ASEAN government to invest in proper governance. With regard to directors' remuneration, ASEAN may adopt a combination of "American" standard when it comes to disclosure and sanctions for non-compliance, and "European" standard when it comes to board independence, remuneration committees and the separation of the roles of the Chairman of BOD and CEO (Pepper, 2006). However, the challenge is an uphill task. In some ASEAN corporations like family oriented enterprises, government linked companies or closely held entities; the good corporate governance practice remains debatable. In addition, there exists a multiple agency relationship within the organizational set up. For instance between the owner and the board of directors, between the board and the top management, between top management and middle management and so on, where in all cases, the former is regarded as principal and the latter as the agent (Ramli, Janor, Mohamad and Kamruddin,2006). At any level, there is a possibility of an agency problem to arise because both principal and agent are utility maximizers where there is no guarantee that the agent shall act upon to maximize the benefit (wealth) of the principal (Ramli and Janor, 2005).

Future research shall also examine the development of corporate governance in the remaining ASEAN countries like Vietnam, Myanmar, Brunei, Laos and Cambodia. These countries are doing well in terms of economic development and catching up their five senior brothers (etc. Malaysia, Singapore, Thailand, Indonesia and Philippine). Indeed, Vietnam for instance recently is beating Malaysia, Indonesia and Thailand in receiving foreign investment. However, the corporate governance is considered at infant level. While, ASEAN authorities are making great efforts to improve corporate governance, good public governance is also becoming inventible. The young 
intellectuals and aware citizens have begun scrutinizing the authorities in respect of managing taxpayers' money, eradicating bribery or misuse of power among public officers, and protecting the environment. It also leaves a gap for potential further investigation.

\section{ACKNOWLEDGEMENT} Minerals.

Dr. Talha acknowledges the logistical support provided byKing Fahd University of Petroleum and

\section{REFERENCES}

1. (2005), Code of Corporate Governance 2005 [online resources] http://www.acgaisa.org/public/files/Singapore_Code_of_Corporate_Governance_2005.pdf

2. $\quad$ Baltazar, W.A. (2002), Corporate Governance in the Philippines. [online resources] http://www.dlsu.edu.ph/research/centers/cberd/pdf/bus focus/CorporateGovernance.pdf

3. Chan Robles Virtual Law Library (n.d.) Memorandum Circular No. 02 Series of 2002 Code of Corporate Governance. [Online resources] http://www.chanrobles.com/secmemorandumcircularno022002.html

4. Fama, E.F. and Jensen, M.C (1983), Separation of Ownership and Control. Journal of Law and Economics, 26(2), pp $301-325$.

5. Malaysian Securities Commission (2007), Malaysian Code of Corporate Governance (Revised 2007.) Securities Commission. Kuala Lumpur.

6. Mak, Y.T. and Ching, C.K. (2000), Corporate Governance Practices and Disclosures in Singapore: An Update [online resources] Available from http://www.oecd.org/dataoecd/6/17/1931014.pdf

7. National Committee on Corporate Governance (2001), Indonesian Code for Corporate Governance [online resources] http://www.ecgi.org/codes/documents/indon_2001.pdf

8. Pepper, S. (2006), Senior Executive Reward: Key Model And Practices. Gower Publishing Limited. Hampshire.

9. Ramli, M.I., Janor, R.M., Mohamad, R. and Kamaruddin, K.M. (2006), University Governance: A Brief Comparison Between Developed Countries and Malaysia. Integrity Journal, 1(1), pp 51 - 68.

10. Ramli, M.I and Janor, R.M. (2005), Hadhari Scorecard. Proceeding. Seminar on Islamic Accounting and Balanced Scorecard: Myth or Reality? Universiti Teknologi MARA Terengganu.

11. Stone, A., Hurley, K. and Khemani, R.S. (1998), The Business Environment and Corporate Governance: Strengthening Incentives for Private Sector Performance. Proceeding. World Bank’s 1998 Annual Meeting Program of Seminar.

12. The Stock Exchange of Thailand (2006), The Principle of Good Corporate Governance For Listed Companies [online resources] http://www.cgthailand.org/SetCG/source/document/files/d372272419c8624ed9b5ef3559eb66b_15\%20Prin ciple.pdf

13. The Stock Exchange of Thailand (1999), Code of Best Practice for Directors of Listed Companies. http://www.acgasia.org/public/files/Thai_Code_on_Directors_Oct99.pdf. 
NOTES 